\title{
What happens to workplace pension saving when employers are obliged to enrol employees automatically?
}

\section{Jonathan Cribb ${ }^{1,2}$ (1) $\cdot$ Carl Emmerson $^{1}$}

Published online: 11 September 2019

(c) The Author(s) 2019

\begin{abstract}
We examine the effect of obliging employers to enrol employees automatically into a workplace pension scheme. We exploit the phased roll-out of automatic enrolment, by employer size, in the first country to do so nationwide (the UK), to estimate its effect on pension saving among private sector employees. We find substantial increases in pension participation and a rise in pension saving. Surprisingly, many newly enrolled employees received an employer contribution substantially above the (very low) minimum default level. Automatic enrolment also caused the pension participation of those employees who were not obliged to be automatically enrolled to more than double.
\end{abstract}

Keywords Automatic enrolment $\cdot$ Private pensions $\cdot$ Non-wage benefits

JEL Classification J32 · D14 · J38

\section{Introduction}

There are concerns about individuals undersaving for retirement in countries across the developed world. In response, policymakers have proposed-and economists have studied - a large variety of schemes designed to increase saving for retirement. One instrument to boost saving for retirement of particular interest is 'automatic enrolment' (sometimes termed default enrolment or 'opt-out' design) where

Jonathan Cribb

jonathan.cribb@ifs.org.uk

Carl Emmerson

carl.emmerson@ifs.org.uk

1 Institute for Fiscal Studies, 7 Ridgmount St, London WC1E7AE, UK

2 University College London, London, UK 
employers enrol employees automatically into a workplace pension scheme, which employees can then choose to leave.

Although automatic enrolment has been prominently highlighted as a particular success story of the real-world implementation of the insights of behavioural economics (Benartzi and Thaler 2013; Madrian 2014; Chetty 2015; Thaler 2016), until now almost all the evidence on the impact of automatic enrolment on participation in employer-provided pensions and pension saving comes from the voluntary introduction of automatic enrolment by large firms in the USA (Madrian and Shea (2001) and Choi et al. (2004); though Chetty et al. (2014) study a case in Denmark). In many cases, these firms have introduced automatic enrolment to comply with the Internal Revenue Service's non-discrimination rules (see Choi et al. 2002; Butrica and Karamcheva 2015). ${ }^{1}$ However, the effects of automatic enrolment on pension saving when employers do not voluntarily choose to introduce it (and are instead obliged by government to enrol their employees automatically) may be differentparticularly if employers take action to limit pension participation, such as by providing low employer pension contributions.

This paper studies the effect of obliging employers to enrol their employees into a workplace pension, using the first ever introduction of such a policy on a nationwide scale. Specifically, we exploit the phased roll-out, by employer size, in the UK of the obligation for employers to enrol most of their employees into a pension automatically since 2012 to estimate its effect on saving in a workplace pension by private sector employees. The roll-out from largest to smallest employers introduces exogenous variation in the timing of when employers were obliged to enrol their employees in a workplace pension scheme, which we exploit using a difference-indifferences methodology. This paper provides the first assessment of the impact of automatic enrolment that allows for changes in employer behaviour in response to the policy in a context where those employers did not choose to introduce automatic enrolment. This kind of impact cannot be identified when automatic enrolment is introduced voluntarily by some large employers.

We find that obliging employers to implement automatic enrolment in the UK led to large increases in the pension participation rates and in the total contributions to workplace pensions. For targeted private sector employees, automatic enrolment led to an increase of 36 percentage points in the probability of participating in a workplace pension scheme. By $2015,88 \%$ of targeted private sector employees who were enrolled automatically were a member of a workplace pension. The largest effects on pension participation are for those with the lowest participation rates prior to automatic enrolment: those in their 20s, lower-paid employees, those who have joined their employer more recently, and those employed in industries with low pre-reform rates of pension participation.

\footnotetext{
1 These rules essentially say that employee benefits cannot be only provided to highly paid employees. Since low-paid employees are less likely to enrol in a pension plan (and receive an employer contribution to the pension scheme) than their higher-paid colleagues, this risks companies failing to comply with the non-discrimination tests. Brady (2007) examines the incentive that firms have to introduce automatic enrolment in order to pay higher-earning employees a larger fraction of their compensation in pension benefits.
} 
The policy is found to have increased the total contribution rate to a workplace pension by $1.05 \%$ of earnings, compared with a pre-reform average of $7.0 \%$, therefore significantly boosting pension saving. One of the reasons that automatic enrolment has increased workplace pension savings is that employers' decisions have boosted-rather than mitigated-the impact on pension savings. We find some employers enrolling their employees into pension schemes with employer contributions well above the minimum contributions mandated by the government. The effect on pension saving was also increased due to substantial spillover effects of the policy. We find that the pension participation rates of workers who were not obliged to be automatically enrolled increased by 18 percentage points on average, thereby more than doubling the pension participation rate among this group.

There are a number of important reasons that we would expect automatic enrolment to increase workplace pension participation. First, by defaulting employees into a pension scheme, automatic enrolment solves the procrastination problem (in which people think that in future they will save for retirement, but they are naive and continually put it off (O'Donoghue and Rabin 1999)). Second, because automatic enrolment involves default contributions and asset allocations, automatic enrolment makes the decision to participate less complex. Since complexity of a decision is known to lead to individuals putting off the decision to join (Tversky and Shafir 1992), automatic enrolment should therefore lead to higher participation. Third, Beshears et al. (2009) argue that individuals may see the default options under automatic enrolment as implicit advice on the best course of action. This endorsement (from either the employer or government) may lead to more people participating (and at the default contributions). Finally, there are some individuals who are automatically enrolled in a pension who were not previously offered an employer contribution to their pension, and now are offered at least $1 \%$ of qualifying earnings (see more details in Sect. 2.1). These individuals may choose to be in their workplace pension in order to be able to receive the (albeit small) employer contribution that they were not offered before.

Previous empirical evidence on the impact of automatic enrolment has been based on its voluntary introduction largely by employers in the USA. Madrian and Shea (2001) compare two cohorts of employees at a large healthcare firm in the USA, where the cohort hired later were enrolled automatically into a 401(k) scheme with a 3\% default employee contribution. They find that participation rates in the pension scheme increased dramatically for the cohort that were enrolled automatically, with $86 \%$ of employees enrolled in the $401(\mathrm{k})$ after 3-15 months, compared with only $37 \%$ of those who were not subject to automatic enrolment. Moreover, they find that the $3 \%$ default contribution was extremely salient; almost $65 \%$ of the cohort eligible for automatic enrolment had contributions equal to the default rate, and the proportion of the cohort with higher contributions fell, implying that automatic enrolment led to some employees contributing less than they would have in the absence of automatic enrolment. Importantly, Chetty et al. (2014) use Danish administrative data and find that only $15 \%$ of people respond actively to automatic pension contributions (by reducing other saving), implying that, for most people, higher pension saving due to automatic contributions is not offset by reductions in other saving. 
These results are of particular interest because automatic enrolment is becoming more popular among public policymakers internationally. Prior to its introduction in the UK, a small number of countries have introduced policies involving automatic enrolment, but they have been either partial or temporary (in Chile) or alongside a raft of other savings policies (in New Zealand). However, by 2017 several states in the USA (California, Connecticut, Illinois and Oregon) had legislated to introduce automatic enrolment (Munnell et al. 2016) while since 2018 new service recruits to the US military have been auto-enrolled into the Thrift Savings Plan (see Executive Office of the President 2016). Many other developed countries are also planning on (or actively considering) introducing automatic enrolment, including Germany, Ireland and Poland.

The remainder of this paper proceeds as follows. Section 2 describes the institutional setting for pensions in the UK and the details of the introduction of automatic enrolment there. Section 3 describes the data used in this paper, Sect. 4 sets out the empirical strategy, and Sect. 5 presents the results. Section 6 concludes.

\section{Policy background}

\subsection{The UK pensions policy environment}

Here, we briefly set out the UK pensions policy environment. Unlike in many European countries, the UK government does not provide a pension at a level that provides high 'replacement rates' for individuals who are retiring after a full working life. A full public pension (known as a 'state pension') in the UK is $£ 155.65$ (\$202) per week (in 2016-2017), equivalent to just under 30\% of median full-time earnings. ${ }^{2}$ Entitlement is accrued either by paying a payroll tax or by undertaking other 'qualifying' activities such as caring for children or receiving out-of-work benefits. The state pension received is not related to the earnings of the individual during their lifetime. State pensions are not means-tested or subject to an earnings test, but are taxable and can only be claimed from the 'state pension age', which in April 2016 was 65 for men and 63 for women and is rising over time so that it will reach age 66 for both men and women in October 2020. Those reaching the 'state pension age' with more than 10 years' qualifying activities are entitled to some state pension, with the full amount payable to those who have amassed 35 years of contributions. As a result, public spending on state pensions in the UK is $5.6 \%$ of GDP, which is slightly lower than the USA (6.7\%) and substantially lower than most other developed countries in continental Europe (OECD 2015).

Given this relatively low level of the state pension, income from private pensions makes up a large proportion of income in retirement for individuals in the UK. Crawford and O'Dea (2012) find that, in 2008-2009, median private pension wealth of those between 50 and the state pension age was $£ 90,700(\$ 118,000)$, while

\footnotetext{
${ }^{2}$ We describe here the state pension system from April 2016, which will be the system for the vast majority of employees currently working in the UK.
} 
$25 \%$ of individuals had private pension wealth of over $£ 237,800(\$ 309,000)$. Individuals who contribute to a pension scheme (and/or receive contributions from their employer) typically make contributions to their pension scheme before income tax and any return from the investments is reinvested untaxed in the pension. Income tax is paid upon drawing a pension, although up to one-quarter of the pension pot can be taken free of income tax.

While a large majority of public sector workers are active members of an employer-provided pension scheme ( $85 \%$ in 2012), only $36 \%$ of private sector employees were in 2012; the latter figure had fallen from 50\% in 1997 (Cribb and Emmerson 2016a). Prior to October 2012 (when automatic enrolment started), all employers with five or more employees were obliged, if requested by an employee, to facilitate participation in a pension scheme where employees' contributions could be deducted directly from employees' pay packets, although employers were not obliged to make contributions to a scheme.

Finally, it should be noted that prior to the introduction of automatic enrolment by the government, it was relatively uncommon for private sector employers to enrol their employees automatically into a pension scheme. McKay (2006) finds that only $4 \%$ of private sector employers (representing $16 \%$ of private sector employees) enrolled their workers automatically into a scheme in 2005.

\subsection{Introduction of automatic enrolment in the UK}

Following the recommendation of the independent 'Pensions Commission' in 2005, the UK government legislated in the Pensions Act 2008 to oblige employers to enrol most of their employees automatically into a workplace pension scheme with at least a minimum level of contributions. A workplace pension scheme is a scheme that is facilitated-but not necessarily run-by the employer. The introduction of automatic enrolment was recommended due to a falling proportion of employees saving in a pension and fears of undersaving for retirement (see Pensions Commission 2005). The obligation to enrol most employees automatically has been introduced gradually, starting in October 2012. Here, we set out the details of the policy as they were implemented by the government.

Employees are 'targeted' if they are aged at least 22, are aged below the state pension age and earn more than a given earnings level. ${ }^{3}$ Since April 2014, this level has been set at $£ 10,000(\$ 13,000)$ per year. Employers can postpone automatically enrolling new employees for up to 3 months. Once automatic enrolment is introduced by the employer, all targeted employees must be enrolled into a pension scheme, which they are then able to choose to leave at any point, although they will be automatically re-enrolled every three years.

Employers introducing automatic enrolment must enrol their employees into a pension with (at least) minimum levels of contributions. Up to and including March

\footnotetext{
3 The UK government terms 'targeted' employees as 'eligible' for automatic enrolment and those who are not targeted as 'non-eligible'. This is a misnomer because 'non-eligibles' can be, and sometimes are, automatically enrolled.
} 
2018, the minimum employer contribution was $1 \%$ of qualifying earnings and the minimum total contribution is $2 \%$ of qualifying earnings, where the 'total' is the sum of employee and employer contributions, including any tax relief. 'Qualifying earnings' are earnings in a certain band set by the government. In 2015-2016, qualifying earnings were those between $£ 5824(\$ 7600)$ and $£ 42,385(\$ 55,100)$ per year. The minimum total contribution increased to $5 \%$ of qualifying earnings in April 2018 (with a minimum of 2\% from the employer) and rose to $8 \%$ from April 2019 (with a minimum of 3\% from the employer). Employers can choose to enrol their employees automatically into schemes with higher (employee and employer) contributions, although they are prevented from setting the employee contribution rate so high as deliberately to encourage a large proportion of employees to opt out, although there is not an explicit cap on this.

The obligation of employers to enrol their targeted employees automatically has been introduced gradually since October 2012. Each employer is given a 'staging date'. Employers must automatically enrol targeted employees from this date, although they can apply to postpone enrolment by up to 3 months from the staging date. ${ }^{4}$ This means that any employer at least 3 months past their staging date must have introduced automatic enrolment, otherwise they will be in breach of their legal obligations.

An employer's staging date is determined by the number of employees the organisation employs in April 2012, as measured by the number of employees on its PayAs-You-Earn scheme (the scheme by which income and payroll tax payments are withheld from employees' earnings). Because employer size is measured at a fixed date in April 2012, it cannot be manipulated by employers as automatic enrolment is rolled out. Employers with 120,000 or more employees were the first employers to be affected, with a staging date of 1 October 2012. Over time, the obligation to enrol targeted employees automatically has been rolled out to affect progressively smaller employers. The exact timetable for the roll-out is included in Table 7 in the Appendix. By April 2015 (which is the latest date covered by the data we use in this paper), all employers with 58 or more employees are obliged to have introduced automatic enrolment. By February 2018, automatic enrolment applied to all employers.

Finally, there are groups of employees who are not enrolled automatically into a pension scheme, but are nonetheless potentially affected by automatic enrolment. Individuals who earn over the earnings threshold, but are aged 16-21 or over the state pension age (but under 75), as well as individuals of all ages earning between $£ 5824$ (\$7600) and $£ 10,000(\$ 13,000)$ per year (in 2015-2016) do not have to be enrolled automatically; however, they can opt into joining the scheme, and if they do their employer must make minimum contributions. Employees earning below $£ 5824$ (\$7600) per year (in 2015-2016) are also not enrolled automatically but can apply to join a pension scheme, although their employer does not have to make a contribution.

\footnotetext{
4 The exception to this is that if an employer has an open DB pension scheme which all employees are entitled to join then they can delay introduction of automatic enrolment until 30 September 2017. However, there are very few open DB schemes in the private sector.
} 


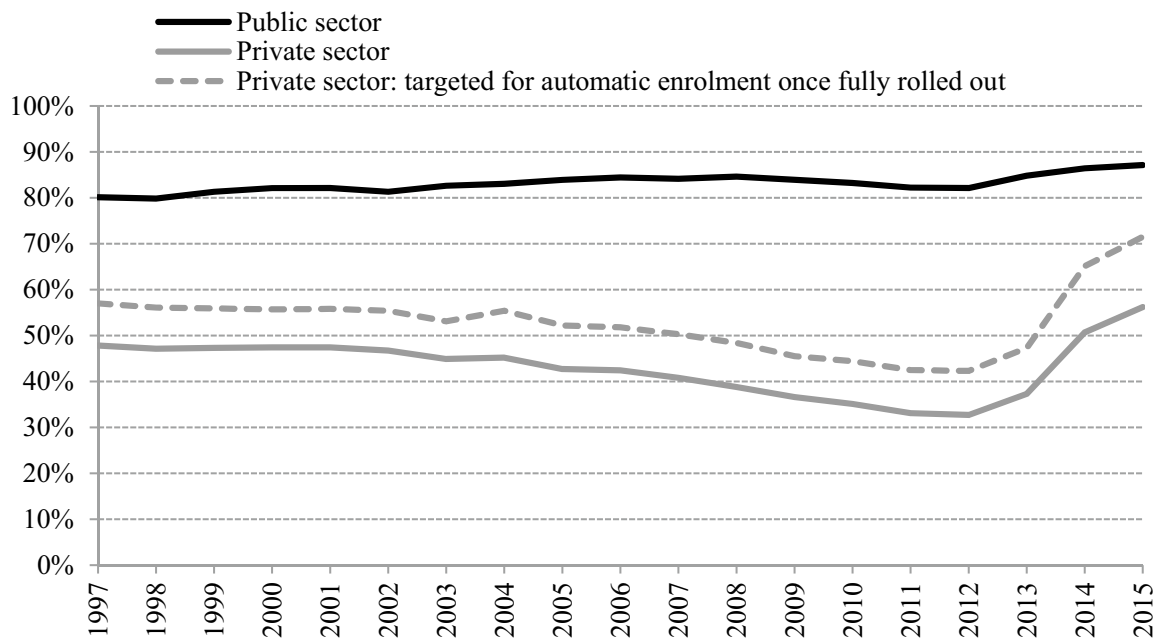

Fig. 1 Workplace pension participation rates among public and private sector employees, 1997-2015. Note: 'Targeted' means those aged 22 to state pension age, earnings over automatic enrolment threshold, working for employer for over 3 months. It does not restrict to those employers where automatic enrolment had been introduced. Source: Authors' calculations using the Annual Survey of Hours and Earnings

\section{Data}

The data used in this paper are from the Annual Survey of Hours and Earnings (ASHE), which is collected by the UK's Office for National Statistics (see Office for National Statistics 2018). ASHE is a panel survey of approximately $1 \%$ of employees in Britain. Employees are included in the survey if their National Insurance number ends in a specific pair of digits. The survey is completed by employers in April of each year, and data are available from April 1997 to April 2015. The number of responses to this survey was 181,052 in $2015 .^{5}$

The ASHE data include detailed information on the pay and hours of work of each employee, and it asks whether the employee was a member of a workplace pension scheme ('run or facilitated by [the] organisation'). From 2004 onwards, it also asks how much the employer and the employee contributed to the pension. The data contain a number of variables on the employee, such as age, sex, occupation and job tenure. It also contains information on the employer, such as industry and sector. Using these data, we can define the set of individuals who are targeted for automatic enrolment: those aged 22 to state pension age, earning more than the automatic enrolment threshold $(£ 10,000(\$ 13,000)$ per year since April 2014) and who have been working for their employer for at least 3 months.

\footnotetext{
5 In 2007 and 2008, the ONS cut the sample size (non-randomly) by approximately $20 \%$. The full sample was restored in 2009. For this reason, with the exception of one descriptive chart (Fig. 1), we restrict our use of these data to the period 2009 to 2015.
} 
Table 1 Distribution of pension contributions for private sector employees, 2012. Source: Authors' calculations using the Annual Survey of Hours and Earnings

\begin{tabular}{|c|c|c|c|c|c|c|}
\hline \multirow[t]{2}{*}{ Contribution rate } & \multicolumn{3}{|l|}{ All } & \multicolumn{3}{|c|}{$\begin{array}{l}\text { All targeted by April } 2015 \text { : targeted work- } \\
\text { ers in employers with } 58+\text { employees }\end{array}$} \\
\hline & Employee (\%) & Employer (\%) & Total (\%) & Employee (\%) & Employer (\%) & Total (\%) \\
\hline None & 73.5 & 68.8 & 67.9 & 59.6 & 53.1 & 52.0 \\
\hline $0-1 \%$ & 0.3 & 0.3 & 0.2 & 0.5 & 0.4 & 0.2 \\
\hline $1-2 \%$ & 1.6 & 0.8 & 0.4 & 2.3 & 1.0 & 0.4 \\
\hline $2-5 \%$ & 12.2 & 6.7 & 2.9 & 18.3 & 9.1 & 3.7 \\
\hline $5-10 \%$ & 11.4 & 9.8 & 8.5 & 18.0 & 15.4 & 12.2 \\
\hline $10-15 \%$ & 0.6 & 7.8 & 6.9 & 0.9 & 11.4 & 11.0 \\
\hline $15 \%+$ & 0.3 & 5.9 & 13.2 & 0.4 & 9.7 & 20.6 \\
\hline All & 100.0 & 100.0 & 100.0 & 100.0 & 100.0 & 100.0 \\
\hline
\end{tabular}

Contribution rates are expressed as weekly contribution to pension scheme divided by gross weekly earnings. For employee and employer contributions, 'None' includes both employees who are in a pension, but where either the employee or employer makes no contribution to it, and employees not in a pension. Columns do not always sum to 100 due to rounding

Most importantly for our empirical strategy, the data contain a measure of the number of employees in the employer in each year. This measure comes from the UK government's business register. This is crucial because, as was discussed in Sect. 2, it is the number of employees employed in April 2012 that determines when employers are obliged to introduce automatic enrolment. Our main outcomes of interest are the participation in a workplace pension scheme and the pension contribution rates. ${ }^{6}$ It is instructive to show the rates of pension participation and the contributions to workplace pensions prior to automatic enrolment being introduced. Figure 1 uses the ASHE data to show how pension participation has changed from 1997 to 2015. Public and private sector workers have had very different participation rates in pensions. The proportion of private sector employees in a workplace pension scheme fell from $48 \%$ in 1997 to $33 \%$ in 2012, before rising to $56 \%$ in 2015 , indicating that automatic enrolment has potentially increased pension participation. Looking only at those meeting the automatic enrolment eligibility requirements (those aged 22 to the state pension age, earning over the threshold and in work, but not restricting to those employers where automatic enrolment had been introduced), it fell throughout the 2000 s, before rising from $42 \%$ in 2012 to $72 \%$ in 2015 . In contrast, pension participation of public sectors is much higher (at least $80 \%$ in all years 1997-2015), though it has also risen since 2012, to reach $87 \%$ in 2015.

\footnotetext{
6 We define an individual to be participating in a workplace pension scheme if their employer indicates they are a member of a workplace pension scheme and the employer does not record there being a zero contribution to the pension (from employee and employer combined). We calculate pension contribution rates by dividing the amount contributed by employee or employer by total pay in the pay period. Employee and employer pension contribution rates are top-coded at the 99th percentile of the distribution of the contribution rates of private sector employees who are in a pension scheme in 2012 .
} 
The focus of this paper is on participation in, and contributions to, workplace pensions among private sector employees. Table 1 shows the distribution of pension contribution rates among all private sector employees (including non-participants) from employees, employers and total, prior to automatic enrolment (in April 2012). It shows that there are very few employees with very low, positive contribution rates, which are the levels at which the minimum contributions are set under automatic enrolment. Looking at employee contributions, $24 \%$ of employees contribute between 2 and $10 \%$, with very few contributing more than $10 \%$. On the other hand, $14 \%$ of employees have an employer contribution of more than $10 \%$ of earnings. Looking only at those who are targeted for automatic enrolment working for an employer with 58 or more employees (and therefore auto-enrolled by April 2015), they are much more likely to have higher employer and employee contribution rates.

In Appendix Tables 8 and 9, we provide descriptive statistics on private sector employees in 2012 working in employers with 58 or more employees who are targeted for automatic enrolment. They have median gross weekly earnings of $£ 460$ (\$600), 61\% are male, $89 \%$ work full-time, over $50 \%$ of them have worked for their employer for five years or more, they have a median age of 41 and they work across a wide range of industries, of which the largest are 'retail and wholesale' and 'manufacturing', employing $20 \%$ and $16 \%$ of the employees, respectively.

\section{Empirical methodology}

The roll-out of the obligation to enrol targeted employees automatically means that we can estimate the causal effect of automatic enrolment on participation in a workplace pension, and the contributions into it, using a difference-in-differences empirical strategy. Employees (and employers) are affected by automatic enrolment at a given time exogenously based entirely on how many employees there were in 2012 and the roll-out timetable chosen by the government, as described in Sect. 2.1. We only consider private sector employees since public sector employees had much higher workplace pension participation rates and many public sector pension plans implemented automatic enrolment prior to the latest reforms coming into effect.

Exploiting the government's roll-out, we categorise private sector employees into 7 'employer size groups' 7 The groups are shown in Table 2. These groups are determined by rules of the roll-out and aggregate together employers who face the same obligation (to enrol targeted employees automatically) when they are observed in each April. In each year from 2013 to 2015, there are some employers who have passed their staging date, but are not 3 months past their staging date, which means

\footnotetext{
7 We exclude individuals who work for employers who had between one and four employees in 2012. This is because the pension participation and contributions rates are unlikely to evolve in a similar way to those for larger employers, partly because many employers with only one employee may be sole proprietors. Moreover, prior to 2012, employers with fewer than five employees did not have to make payroll deductions to a pension scheme if requested by the employee.
} 
Table 2 Roll-out of automatic enrolment obligations by employer size. Source: Authors' calculations using http://www. nowpensions.com/auto-enrol ment-staging-dates/ and the Annual Survey of Hours and Earnings

\begin{tabular}{lllll}
\hline Employer size & \multicolumn{4}{l}{ Was automatic enrolment in place in: } \\
\cline { 2 - 5 } in April 2012 & April 2012 & April 2013 & April 2014 & April 2015 \\
\hline $30,000+$ & No & Yes & Yes & Yes \\
$6000-29,999$ & No & Partially & Yes & Yes \\
$350-5999$ & No & No & Yes & Yes \\
$160-349$ & No & No & Partially & Yes \\
$58-159$ & No & No & No & Yes \\
$50-57$ & No & No & No & Partially \\
$5-49$ & No & No & No & No \\
\hline
\end{tabular}

that they could have introduced automatic enrolment but they might not have because they might have postponed its introduction. We term these groups 'partially affected' and control for them in our analysis below.

Given this roll-out, Eq. (1) sets out the difference-in-difference specification that we use to estimate the impact of automatic enrolment:

$$
y_{i f t}=\alpha+\beta(\text { autoenrol })_{i f t}+\sum_{a=2013}^{2015} \gamma_{a}[\text { partial_a } a=1]+\theta_{f}+\mu_{t}+\delta X_{i f t}+\varepsilon_{i f t} .
$$

We want to estimate the effect of automatic enrolment on an outcome (such as pension participation) $y$, for an individual $i$, working for an employer in 'employer size group' $f$, observed at time $t$. (autoenrol) ift $_{f}$ is a dummy variable taking the value 1 if automatic enrolment is in place in the employee's employer when they are observed, and 0 otherwise. $\beta$ is the coefficient of interest. It is also necessary to control for the fact that some employees work for employers that are 'partially affected'. We therefore introduce a dummy variable for being 'partially affected', which varies for each year that there are people who are partially affected (2013-2015): $\sum_{a=2013}^{2015} \gamma_{a}[$ partial_a $a=1] .8$

We control for fixed differences in the outcome for employees working for employers of different sizes using six 'employer size group' fixed effects $\theta_{f}$. We control for time using year fixed effects $\mu_{t}$. Under this specification, we assume that the 'employer size group' fixed effects are fixed over time. This is the usual common trends assumption which says that, in the absence of the reform, affected and unaffected employees would see their pension participation and contribution rates change in the same way.

We also control for a vector of characteristics of employees and the employers they work for, $X$. These include controls for sex, age (in cubic), job tenure (three

\footnotetext{
8 These coefficients on the partially affected dummies are allowed to vary by year because in different years the average gap between April and the month of the staging date (February, March or April) varies. Restricting these coefficients to be the same does not affect our results.
} 


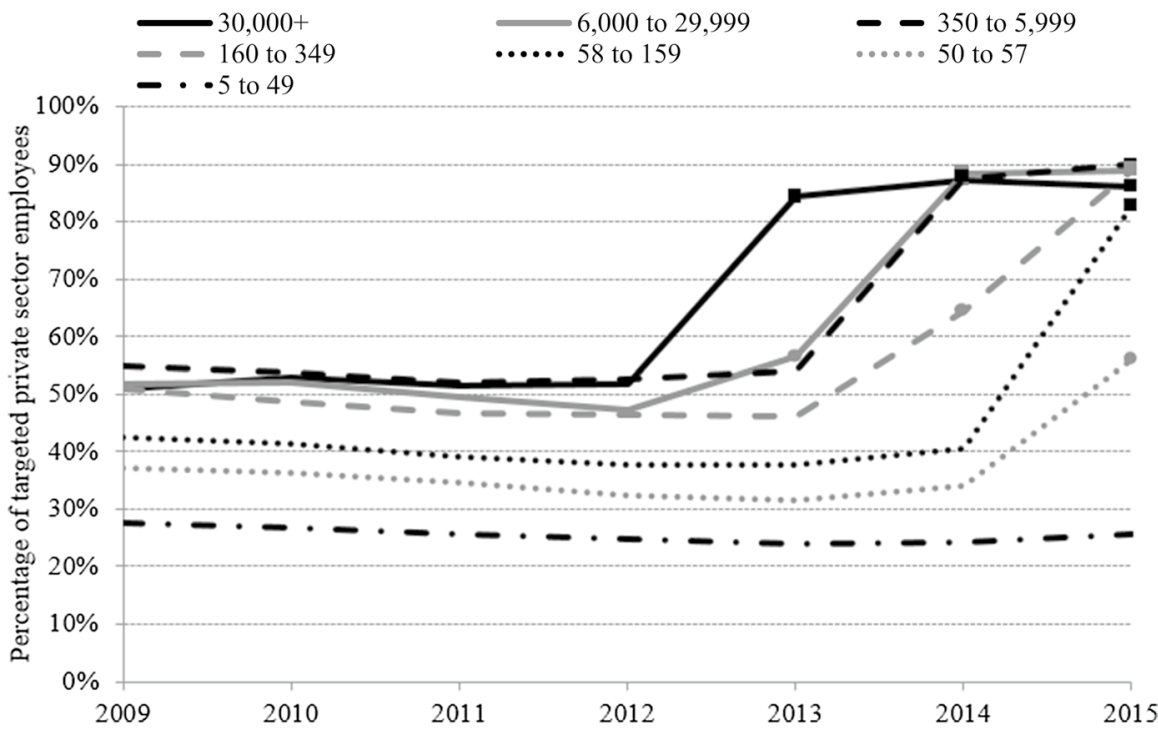

Fig. 2 Workplace pension participation rates among private sector employees targeted for automatic enrolment, by employer size in 2012. Note: Square data points indicate periods when employers were at least 3 months past their staging date and therefore had to enrol their targeted employees automatically. Circular data points indicate employers that are past their staging date, but not 3 months past their staging date and so are 'partially affected'. Source: Authors' calculations using the Annual Survey of Hours and Earnings

dummies), dummies for working for a non-profit institution, being in a full-time job, the job not being the individual's 'main' job and the job being temporary, 10 regional dummies, 12 dummies for industry of the employer and 8 dummies for occupational category of the employee. The full list of covariates is found in Appendix Table 11.

Figure 2 provides graphical evidence for the effect of automatic enrolment on the pension participation rate of private sector employees who meet the conditions for auto-enrolment. ${ }^{9}$ Each series represents employees working for private sector employers of different sizes. Prior to the introduction of automatic enrolment (between 2009 and 2012), the participation rates of each group move in a similar way, although, on average, employees working for larger employers have higher participation rates than those working for smaller employers. This suggests that - at least prior to the reform-our common trends assumption needed for identification of a causal effect is valid.

\footnotetext{
9 The data underlying Fig. 2, and the analysis in the remainder of the paper, include one observation per job rather than one observation per person. Therefore, if an individual has two jobs, they are included in the data twice. We do not restrict the analysis to main jobs because automatic enrolment operates at the 'job level': if an individual is in a job and they meet the requirements for auto-enrolment, they will be enrolled automatically, even if it is not their main job.
} 
In Fig. 2, data points in which employees are enrolled automatically are shown with a square data point. Those periods in which employees are enrolled automatically see far higher pension participation rates than prior to automatic enrolment, with participation rates under auto-enrolment of between 80 and $90 \%$, suggesting that there is a large impact of automatic enrolment on pension participation. Unsurprisingly, partially affected groups (denoted by circles in Fig. 2) have higher participation than before automatic enrolment, but not as high as when it is fully introduced. The primary outcomes of interest are the effects of automatic enrolment on the probability of participation in a workplace pension scheme and on the level and distribution of pension contributions. We estimate the effect on the probability of pension participation using a linear probability model and a probit model, and the effect on contribution rates (both mean and whether below different thresholds) using ordinary least squares (OLS). The models are estimated on data from April 2011 to April 2015, therefore including two years (2011 and 2012) in which nobody was affected by automatic enrolment and three years in which progressively more employees are enrolled automatically. Our sample size of targeted private sector employees in employers with five or more employees from 2011 to 2015 is 457,443, working for 64,849 employers. The sample size for each 'employer size group' in each year is shown in Appendix Table 10. There are a small number of employees with missing pension contributions, so the sample size for the effect on pension contributions is slightly smaller at 452,212.

Since automatic enrolment is implemented by employers, and they may implement it in slightly different ways (particularly in terms of how much they offer as an employer contribution), there may be a correlation in the error $\varepsilon_{i f t}$ between employees working for the same employer. In all our results, we therefore cluster our standard errors at the employer level. We show the number of clusters (employers) as well as the number of observations (employees) underlying each regression in the Results section.

\section{Results}

\subsection{Effect of automatic enrolment on participation of a workplace pension}

Table 3 reports the results of estimating the effect of automatic enrolment on the proportion of employees who are members of a workplace pension, using Eq. (1), with the dependent variable being a dummy indicating whether the employee is participating in a workplace pension. Our preferred specification is specification 2 , which estimates the effect by ordinary least squares (OLS), controlling for the characteristics of employees $(X)$. We find that automatic enrolment substantially increases the proportion of employees participating in a workplace pension, by 36 percentage points. ${ }^{10}$ This compares with a pre-reform (2012) participation rate of $49 \%$ of targeted employees working for employers with 58 or more employees.

\footnotetext{
${ }^{10}$ Almost all of this 36 percentage point increase was due to increased participation in DC pension schemes (a 35 percentage point effect), with only a 1 percentage point increase in participation in DB schemes, an effect which is not statistically significantly different from zero at standard significance levels.
} 
Table 3 Effect of automatic enrolment on pension participation rates of targeted private sector employees. Source: Authors' calculations using the Annual Survey of Hours and Earnings

Effect of automatic enrolment

Standard error

Number of observations

Number of clusters

Estimated by:

Control variables $(X)$ included?
(1)

$0.365 * * *$
$[0.016]$
457,443
64,849
OLS
No

(2)

(3)

$0.361 * * *$

[0.016]

457,443

64,849

OLS

Yes
(4)

$\begin{array}{ll}0.376^{* * *} * & 0.368 * * * \\ {[0.018]} & {[0.017]} \\ 457,443 & 457,443 \\ 64,849 & 64,849 \\ \text { Probit } & \text { Probit } \\ \text { No } & \text { Yes }\end{array}$

*** Denotes that the effect is significantly different from zero at the $1 \%$ level, ** at the $5 \%$ level and * at the $10 \%$ level. Probit models are estimated using maximum likelihood. Standard errors are clustered at the employer level and for specifications 3 and 4 are estimated by bootstrapping the average marginal effect of automatic enrolment on pension participation 250 times. Control variables $(X)$ are listed in Appendix Table 11. Sample includes all targeted private sector employees from April 2011 to April 2015

The alternative specifications in Table 3 show that this result is robust to estimating the model using a probit model (specifications 3 and 4) rather than OLS (as shown in specifications 1 and 2) and to not controlling for control variables $X$ (specifications 1 and 3). The full results of the OLS regression (in specification 2) are shown in Appendix Table 11. In all the results in Table 3, the effect of automatic enrolment is highly significantly different from zero (at below the $1 \%$ level).

We test the validity of this empirical strategy using a placebo test, in which we imagine that automatic enrolment had been introduced in exactly the same way, but 3 years earlier. We then estimate the same Eq. (1), except using data from 2009 to 2012 (all years are prior to auto-enrolment actually being introduced). The results of this test are shown in Appendix Table 12. We find that there is no evidence of any effect, with the tiny point estimate of 0.2 percentage points not being close to being statistically significant.

By 2015, targeted employees in employers of the same size had a pension participation rate of $88 \%$. With pension participation rates under automatic enrolment nearing $90 \%$, these are very similar to the rates found by Madrian and Shea (2001) and Choi et al. (2004) in their studies of US firms. However, the increase in participation in workplace pensions caused by automatic enrolment is heterogeneous, which is not surprising because, prior to automatic enrolment, different groups of workers had very different participation rates.

Table 4 shows the effect of automatic enrolment on different subgroups. These are the results of estimating Eq. (1) only on given subgroups (using a linear probability model and including control variables). Overall, it shows that those groups that had the lowest pre-reform pension participation rates see the largest impact of automatic enrolment, but that those groups with the highest pre-automatic enrolment participation rates still have the highest rates after its introduction. For example, automatic enrolment increased pension participation of 22- to 29-year-olds by 52 percentage points, compared with a baseline of $28 \%$, whereas the effect for those in their $40 \mathrm{~s}$ was 31 percentage points, compared with a base of $56 \%$. By 2015, the participation rate of targeted employees in employers with 58 or more employees was $85 \%$ for those in their 20 s, compared with $90 \%$ for those in their 40 s. 
Table 4 Effect of automatic enrolment on pension participation rates of different subgroups. Source: Authors' calculations using the Annual Survey of Hours and Earnings

\begin{tabular}{|c|c|c|c|c|c|c|}
\hline & \multirow[t]{2}{*}{ Effect } & \multirow[t]{2}{*}{ Std error } & \multirow[t]{2}{*}{ Sample size } & \multirow[t]{2}{*}{ Number of clusters } & \multicolumn{2}{|c|}{ Participation rate in } \\
\hline & & & & & $2012(\%)$ & $2015(\%)$ \\
\hline All & $0.361 * * *$ & {$[0.016]$} & 457,443 & 64,849 & 48.6 & 88.1 \\
\hline \multicolumn{7}{|l|}{ Age group } \\
\hline $22-29$ & $0.521 * * *$ & {$[0.023]$} & 94,294 & 24,329 & 27.6 & 85.4 \\
\hline $30-39$ & $0.372 * * *$ & {$[0.017]$} & 116,337 & 25,480 & 48.0 & 88.4 \\
\hline $40-49$ & $0.306 * * *$ & {$[0.016]$} & 124,806 & 25,370 & 56.4 & 89.9 \\
\hline 50 to state pension age & $0.279 * * *$ & {$[0.013]$} & 122,006 & 23,570 & 57.7 & 88.0 \\
\hline \multicolumn{7}{|c|}{ Job tenure (years with employer) } \\
\hline$<1$ year & $0.538 * * *$ & {$[0.013]$} & 49,771 & 23,459 & 21.6 & 81.3 \\
\hline $1-2$ years & $0.494 * * *$ & {$[0.016]$} & 54,653 & 25,773 & 30.0 & 86.1 \\
\hline $2-5$ years & $0.444 * * *$ & {$[0.019]$} & 109,154 & 30,377 & 38.2 & 87.3 \\
\hline$\geq 5$ years & $0.266^{* * *}$ & {$[0.016]$} & 243,865 & 34,820 & 62.0 & 90.4 \\
\hline \multicolumn{7}{|l|}{ Earnings quartile } \\
\hline Lowest quartile & $0.539 * * *$ & {$[0.035]$} & 114,361 & 28,007 & 22.3 & 81.1 \\
\hline Second quartile & $0.457 * * *$ & {$[0.020]$} & 114,361 & 28,805 & 36.0 & 86.1 \\
\hline Third quartile & $0.315^{* * *} *$ & {$[0.013]$} & 114,362 & 25,907 & 55.5 & 89.5 \\
\hline Fourth quartile & $0.161 * * *$ & [0.009] & 114,359 & 19,071 & 76.6 & 93.5 \\
\hline \multicolumn{7}{|l|}{ Sex } \\
\hline Male & $0.356 * * *$ & {$[0.016]$} & 275,633 & 42,758 & 50.0 & 88.7 \\
\hline Female & $0.369 * * *$ & {$[0.018]$} & 181,810 & 32,757 & 46.4 & 87.1 \\
\hline \multicolumn{7}{|c|}{ Industry's pension participation pre-reform } \\
\hline Lowest third & $0.619 * * *$ & {$[0.011]$} & 142,384 & 26,149 & 18.7 & 83.9 \\
\hline Middle third & $0.375 * * *$ & {$[0.038]$} & 141,164 & 21,020 & 44.7 & 86.8 \\
\hline Highest third & $0.151 * * *$ & {$[0.010]$} & 141,549 & 13,915 & 75.3 & 92.3 \\
\hline
\end{tabular}

***Denotes that the effect is significantly different from zero at the $1 \%$ level, $* *$ at the $5 \%$ level and * at the $10 \%$ level. All models are estimated by OLS including control variables (listed in Appendix Table 11). Standard errors clustered at the employer level. 'Participation rate' in 2012 and 2015 is based only on targeted employees working for employers that had 58 or more employees in 2012

Table 4 also shows that there is a larger effect for people with low job tenure than for those with high job tenure-increasing the participation rate by almost 54 percentage points for those in their first year with an employer, compared with 27 percentage points for those with 5 or more years with the employer. Before automatic enrolment, job tenure is highly correlated with pension participation, and while there is still a positive relationship after automatic enrolment, it is much less pronounced.

We also divide the sample into quartiles of the weekly earnings distribution in each year (restricting only to targeted private sector employees) and look at the effect on each quartile. The effect for the lowest earnings quartile of targeted employees (in April 2015, this was composed of those earning between $£ 10,000(\$ 13,000)$ and $£ 16,730(\$ 21,700)$ per year) is 54 percentage points, compared with only 16 percentage points for the highest quartile, with the participation rate for the highest 
quartile reaching $94 \%$ in 2015 . Consistent with this is the fact that those from lower occupational classes see a larger increase in pension participation as a result of automatic enrolment than do those from higher occupational classes (results not reported in the table). There is a slightly larger impact for women than for men (although not statistically significantly different).

The table also shows that the effects of automatic enrolment were much greater in industries that, prior to the reform (i.e. in 2012), had particularly low pension provision. For those targeted employees working in industries in the lowest third of pension participation, the effect of auto-enrolment was to boost pension participation by 62 percentage points, an impact that is even higher than the increase for those with the lowest earnings or shortest job tenure. In comparison, the effect of automatic enrolment for those from high-participation industries was 15 percentage points.

\subsection{Effect of automatic enrolment on workplace pension contribution rates}

While the impact of automatic enrolment on pension participation is clear, the impact on the levels of contributions made into workplace pensions may only be quite small (and could even be negative), if those who are newly enrolled into a pension scheme are enrolled at the legal minima (1\% of qualifying earnings from employer, $2 \%$ of qualifying earnings in total) and if the introduction of the default means that some employees reduce their contributions to the default level, as is found in Madrian and Shea (2001).

We estimate the effect of automatic enrolment on the mean pension contribution rates (from employee/employer/total) using Eq. (1), estimated by OLS. The results of this are shown in Table 5. It shows that there was an increase in the mean employee contribution rate by $0.45 \%$ of earnings, from a baseline of $2.1 \%$ in 2012 (a $21 \%$ increase). The effect on employer contribution rates was larger, at $0.60 \%$ of earnings (although this increase is a lower fraction of the pre-reform mean). The effect on the mean total contribution rate was $1.05 \%$ of earnings,

Table 5 Effect of automatic enrolment on mean employee, employer and total contribution rates to workplace pensions among targeted employees. Source: Authors' calculations using the Annual Survey of Hours and Earnings

\begin{tabular}{llll}
\hline & $\begin{array}{l}\text { Effect of auto- } \\
\text { enrolment }\end{array}$ & Std error & $\begin{array}{l}\text { Mean contribution rate of } \\
\text { targeted employees in 2012 } \\
(\%)\end{array}$ \\
\hline Employee contribution rate & $0.45^{* * *}$ & {$[0.06]$} & 2.1 \\
Employer contribution rate & $0.60^{* * *}$ & {$[0.11]$} & 4.9 \\
Total contribution rate & $1.05^{* * *}$ & {$[0.13]$} & 7.0 \\
\hline
\end{tabular}

$* * *$ Denotes that the effect is significantly different from zero at the $1 \%$ level, $* *$ at the $5 \%$ level and * at the $10 \%$ level. Each regression has 452,212 observations and 64,428 clusters (employers) underlying it, estimated by OLS including control variables (listed in Appendix Table 11). Standard errors clustered at the employer level. Contribution rate is the weekly amount contributed by the employee/employer to the pension, as a fraction of gross weekly earnings. Total contribution rate is the sum of the employee and employer contribution rates 


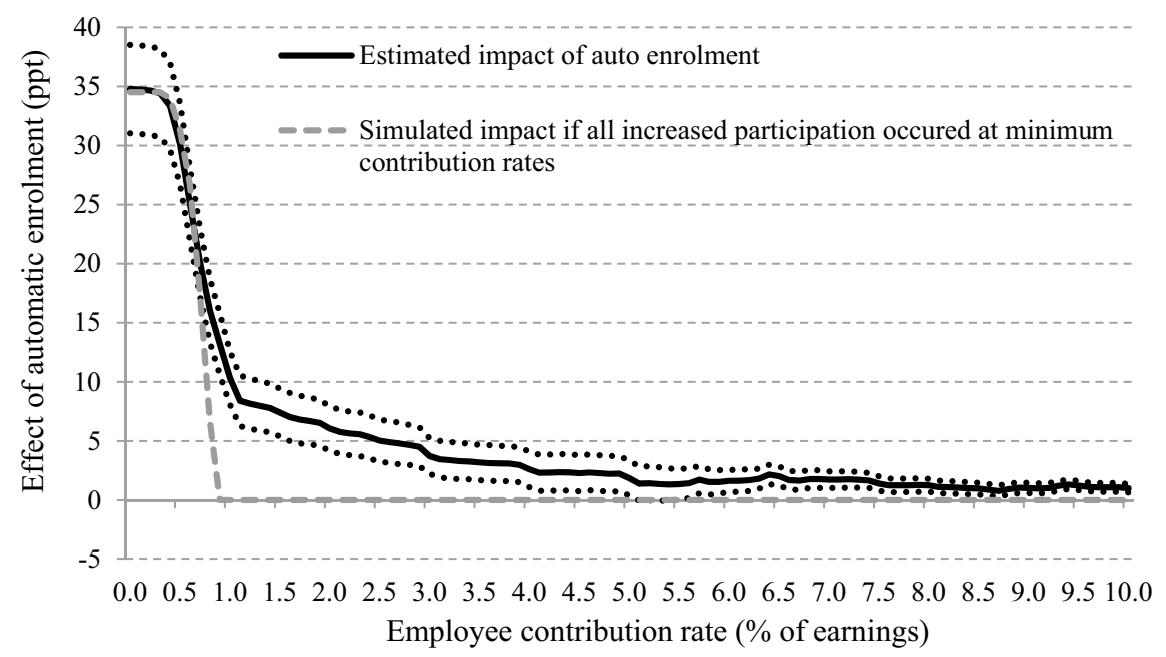

Fig. 3 Effect of automatic enrolment on probability of employee contribution rate being greater than certain percentages of earnings, and the simulated impact if all increased participation occurred at minimum default contributions. Note: Each of the data points (at each $0.1 \%$ of earnings) is the coefficient on autoenrolment from estimating Eq. (1) with the dependent variable being a dummy indicating if the contribution rate is in excess of the specified amount. Each regression is estimated by OLS including control variables (listed in Appendix Table 11). Standard errors are clustered at the employer level and used to construct the $95 \%$ confidence intervals shown in dotted lines. The grey dashed lines show the simulated impact on contribution rates had the entire increase in pension participation occurred at the minimum default contribution rates as specified by government and had no-one else changed their pension saving in response to the reform. Source: Authors' calculations using the Annual Survey of Hours and Earnings

compared with an average contribution rate of $7.0 \%$ in 2012 prior to automatic enrolment being introduced. All of these impacts are statistically significant at the $1 \%$ level. Consistent with the findings in Table 4, we find that the increases in total contributions are largest in the groups (such as those with low earnings and younger employees) that had lower contributions prior to the reform.

Because the mean contribution rate includes zeros and is affected by some high contribution rates (generally from Defined Benefit schemes), it is potentially more interesting to estimate the impact on the distribution of contribution rates. We do this by creating a set of dichotomous variables taking the value one if the individual is contributing (strictly) more than a certain share of earnings, and zero otherwise. We do this for all values from zero to $10 \%$ of earnings in steps of $0.1 \%$ of earnings. This is done separately for employee, employer and total contributions. The impact of automatic enrolment on these outcomes is estimated using Eq. 1, using OLS, and with standard errors clustered at the employer level (analogous to specification 2 from Table 3). The resulting estimated coefficients, alongside their 95\% confidence intervals, are plotted in Figs. 3, 4 and 5.

In addition, on each figure in a grey dashed line, we show the simulated impact of automatic enrolment on the distribution of pension contributions if every employee brought into a pension scheme as a result of automatic enrolment was enrolled with minimum default contributions as specified by the government (and if there was no 


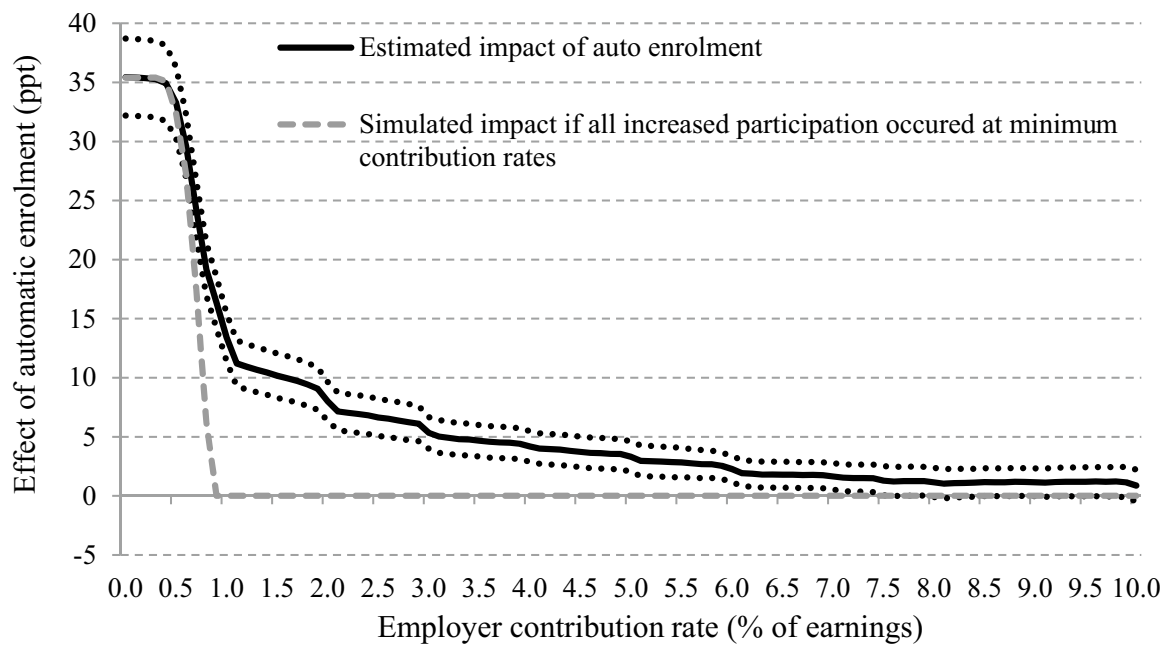

Fig. 4 Effect of automatic enrolment on probability of employer contribution rate being greater than certain percentages of earnings and the simulated impact if all increased participation occurred at minimum default contributions. Note: As Fig. 3. Source: Authors' calculations using the Annual Survey of Hours and Earnings

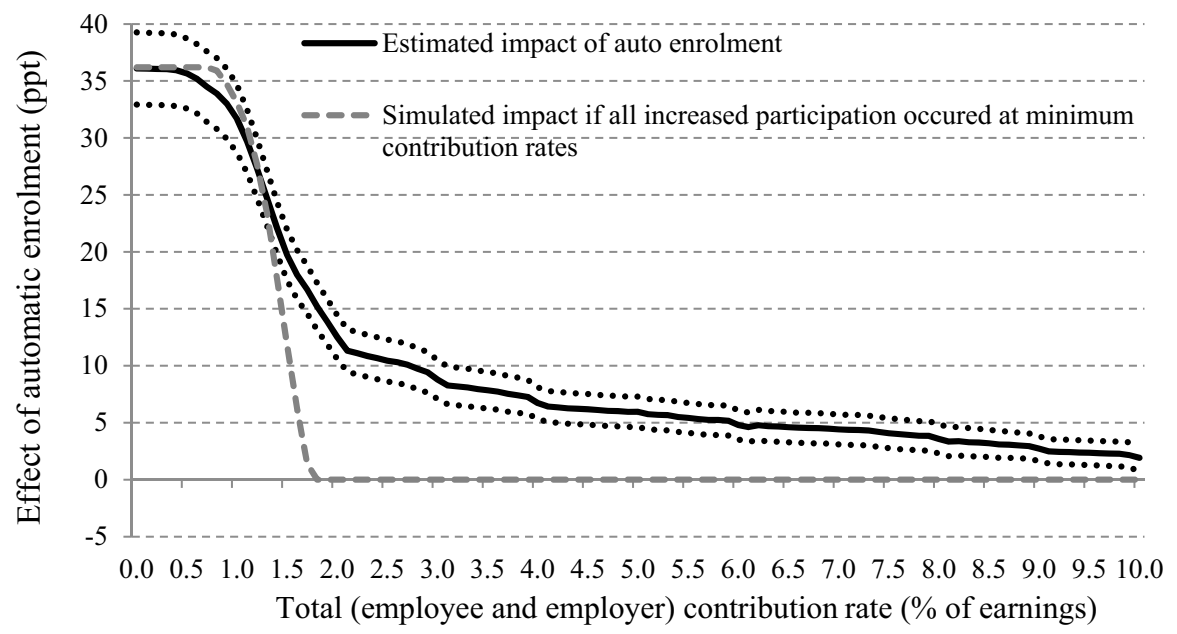

Fig. 5 Effect of automatic enrolment on probability of total contribution rate being greater than certain percentages of earnings and the simulated impact if all increased participation occurred at minimum default contributions. Note: As Fig. 3. Source: Authors' calculations using the Annual Survey of Hours and Earnings

other change in response to the policy). Comparing the estimated impact of automatic enrolment (the solid black lines) with this simulated effect allows us to say to what extent employees are making or receiving higher pension contributions than the minimum defaults as a result of automatic enrolment. 
There are very large increases in the proportion with low positive contribution rates, on both the employee and employer side. Figure 3 shows that there is an increase of 30.1 percentage points in the proportion of employees making an employee contribution over $0.5 \%$ of earnings. The effect on the probability of having an employee contribution rate of over $1 \%$ is smaller, at 10.4 percentage points. As shown in Fig. 4, there is a similar increase in the proportion of employees receiving very low employer contribution rates - an increase of 33.3 percentage points with employer contributions above $0.5 \%$ of earnings, but only a 13.4 percentage points increase with contributions in excess of $1 \%$ of earnings. This shows that the minimum default of $1 \%$ of qualifying earnings as employer contribution has led to a very large increase in the proportion saving small amounts through a workplace pension.

However, by comparing the black lines to the simulated grey lines, Figs. 3 and 4 also show that, on both the employee and employer side, automatic enrolment has caused a large increase in the proportion of employees saving well over the minimum contribution rates. For employee contributions, automatic enrolment has increased the probability of contributions above $2 \%$ of earnings by 6.0 percentage points and above $5 \%$ by 1.9 percentage points. These effects are statistically significant at the $5 \%$ level. On the employee side, this means that individuals are not responding to the default minimum by reducing their contributions towards it, as is found by Madrian and Shea (2001). Instead, there is an increase in the proportion making contributions that are much higher than the minimum.

This is an important result, because one of the concerns with the introduction of automatic enrolment is the fact that it has (in some settings) led to some people saving less, prompting calls for other policies such as auto-escalation (see Benartzi and Thaler (2013)). Although our results do not rule out this behaviour, they show that if it is present then the lower saving is more than outweighed by the effect of employers and employees starting to contribute more than the minimum. One reason for this could be the fact that employers are enrolling their employees automatically into schemes with much higher employer contribution rates than the minimum and that they also have higher minimum employee contributions. Indeed, there are also significant impacts of automatic enrolment on the proportion of targeted employees who are receiving in excess of $2 \%$ in employer contribution (8.0 percentage points) and even on the proportion with employers contributing $5 \%$ or more $(3.3$ percentage points). This also shows that the results are not simply explained by employers choosing to move straight to the long-run minimum contribution rates.

Overall, Fig. 5 shows the effect of automatic enrolment on the total contribution rate-which is what policymakers may care about most given they are aiming to increase retirement savings. Automatic enrolment has led to the proportion with a contribution over $1 \%$ increasing by 31.7 percentage points, over $2 \%$ by 12.5 percentage points, over $5 \%$ by 6.0 percentage points and even an increase in the proportion with over $10 \%$ of 1.9 percentage points. All of these effects are statistically significant at the 5\% level. Overall, therefore, most of the increase in workplace pension contributions comes from very small contributions around the current default minimums, but automatic enrolment also led to considerable increases well above those government minimums. 
One group where employers might have been particularly likely to have reduced their pension contributions in response to automatic enrolment is with newly hired employees. However, when we take those who have worked for their employer for less than a year we still find evidence of a sizeable increase in the proportion of employees, and of employers, who are contributing more than $2 \%$ - and more than $5 \%$ - of their salary to a workplace pension. This is true even when looking at those who might be most likely to receive lower employer contributions-employees aged 22-29, earning less than median earnings, who have worked for their employer for less than a year. ${ }^{11}$

Furthermore, it is notable that this increase in the proportion of employees with contributions in excess of the minimums is not limited only to large employers that have historically provided employees with pensions. Using the same difference-indifferences methodology, and a control group of those employees working for slightly smaller employers, we can look separately at the impact of automatic enrolment on a group of large employers (those with 30,000 + employees) and a group of small employers (58-159 employees). The results of this are shown in Appendix Table 13.

This shows that the effect on pension participation is larger in the group of small employers (41 percentage points) than in the largest employers (30 percentage points). This is mostly as a result of smaller employers having lower pre-reform participation rates and, to a lesser extent, lower participation under automatic enrolment among these employers. However, the effect on the probability of having higher levels of contributions (e.g. more than $2 \%, 5 \%$ or $10 \%$ ) are very similar across larger and smaller employers. This implies two things. First, of those who are brought into a pension by automatic enrolment, a greater percentage of those working for small employers end up on low contributions. Second, it also shows the increase in the probability of having contributions well in excess of the minimums is not limited to the largest employers, but is something that occurs among smaller employers too.

\subsection{Effects of automatic enrolment on non-targeted employees}

Automatic enrolment potentially has impacts on those who are not targeted for automatic enrolment, for three main reasons. First, as described in Sect. 2, those who are not targeted for automatic enrolment but earn at least $£ 5824$ (\$7600) per year can ask to be enrolled in a pension. They may want to do so (even if they did not want to prior to automatic enrolment) as peer effects have been shown to influence pension plan participation (Duflo and Saez 2002), so increased participation of targeted workers might encourage non-targeted workers to ask their employers to enrol them in a scheme. Second, employers automatically enrol employees when they are targeted and employees could continue to participate even if they are no longer formally in the targeted group. Although this is not a possible mechanism for some groups of nontargeted employees - specifically those who have not yet worked for the employer for 3 months and those who are aged under 22-it may be important for those who have

\footnotetext{
11 These results are shown in more detail in the working paper version of this paper. See Table 11 , and surrounding text, in Cribb and Emmerson (2016b).
} 
Table 6 Effect of automatic enrolment on pension participation rates of private sector employees who are not targeted for automatic enrolment. Source: Authors' calculations using the Annual Survey of Hours and Earnings

\begin{tabular}{lllllll}
\hline $\begin{array}{l}\text { Non-targeted group for } \\
\text { automatic enrolment }\end{array}$ & Effect & Std error & $\mathrm{N}$ & Number of clusters & \multicolumn{2}{l}{ Participation rate in } \\
\hline 0-2 months' job tenure & $0.203^{* * *}$ & {$[0.017]$} & 9478 & 5915 & $2012(\%)$ & $2015(\%)$ \\
Aged under 22 & $0.059^{* * *}$ & {$[0.013]$} & 18,476 & 7719 & 11.5 & 32.8 \\
Aged over state pension age & $0.087^{* * *}$ & {$[0.016]$} & 11,567 & 4253 & 29.2 & 38.8 \\
Under earnings threshold & $0.281^{* * *}$ & {$[0.022]$} & 51,059 & 14,971 & 18.4 & 52.1 \\
All not targeted & $0.178^{* * *}$ & {$[0.013]$} & 110,554 & 31,387 & 14.7 & 35.6 \\
\hline
\end{tabular}

$* * *$ Denotes that the effect is significantly different from zero at the $1 \%$ level, $* *$ at the $5 \%$ level and $*$ at the $10 \%$ level. All models are estimated by OLS including control variables (listed in Appendix Table 11). Standard errors clustered at the employer level. Analysis restricted to those earning at least the lower earnings limit (LEL)—£5824 (£7600) per year in 2015-16—in the year they are observed

variable earnings and are automatically enrolled because at some point they earn over the earnings threshold. Third, employers can decide to enrol automatically employees who are not targeted for automatic enrolment under the legislation. There are a number of reasons that employers might do this, such as a paternalistic desire to provide pensions to all staff, including low earners, or to reduce the administrative burden of monitoring whether staff do or do not earn over the earnings threshold in each pay period.

Table 6 shows the effect on different non-targeted groups, by estimating Eq. (1) on non-targeted groups from 2011 to 2015. For the first four rows of the table, we select those who are non-targeted for only one reason (such as being too young, but who would otherwise be targeted). The last row includes employees non-targeted for automatic enrolment for any reason. Table 6 shows that there are significant spillover effects of automatic enrolment onto groups that are not targeted for automatic enrolment under the government rules. Auto-enrolment increases participation rates by 20 percentage points for people who have not yet worked for their employer for 3 months and by 28 percentage points for those earning under the earnings threshold. The spillovers on those aged above and below the age cut-offs are smaller, but still sizeable, with auto-enrolment increasing pension participation by 6 percentage points for individuals who are aged under 22 and by 9 percentage points for those over the state pension age. All of these effects are statistically significant at the $1 \%$ level. Taking all non-targeted private sector employees together (who earn at least $£ 5824$ (\$7600) per year), the effect is to increase pension participation by 18 percentage points-thereby more than doubling pension participation among this group. ${ }^{12}$

The fact that there are large spillover effects of automatic enrolment on the pension participation rates of non-targeted workers is both interesting and important, even though we cannot distinguish the exact mechanism that is causing it at the

\footnotetext{
${ }^{12}$ We do not look at the effect on those earning less than $£ 5824$ ( $\left.\$ 7600\right)$ per year. This is because historically, the ASHE data have captured those employees earning under this threshold (the Lower Earnings Limit, the threshold at which employers start paying employer payroll taxes) relatively poorly.
} 
moment. If it is that these employees are asking to participate, it cannot be that procrastination was causing them not to enrol previously. However, it could be because the decision is now less complex, because of the endorsement factor or in order to receive the employer contribution. Given that there is evidence of employees not enrolling in pension schemes even when there are no mandatory employee contributions (see Benartzi and Thaler (2007)), it might be unlikely that employees asking to participate is the major driver of this impact.

On the other hand, it could be that employers are choosing to enrol their non-targeted employees automatically into a pension scheme, even though this will come at some cost to the employer. This would be more evidence of employers choosing to pay more in pension remuneration than is mandated by the legislation introducing automatic enrolment. One piece of evidence for this is that, when looking at the effect of automatic enrolment on employer contributions of non-targeted employees, the proportion of employees receiving more than $1 \%$ contribution rose by 5 percentage points, suggesting that many of those who are participating are receiving more than the minimum contribution. This conclusion that these results are not driven mainly by opting in is supported by a survey of employers undertaken by Department for Work and Pensions (2016) that reports only very few (5\%) of individuals who are not targeted for automatic enrolment elect to opt into participating in a workplace pension.

Having said this, it is unlikely that this is simply the result of paternalistic employers automatically enrolling employees (that they do not have to) into pension schemes because they believe it is good for their employees. As shown in Appendix Table 14, splitting non-targeted employees into three groups based on the prereform pension participation of the industry of their employer reveals that there have been large increases (18 percentage points) in the proportion of non-targeted employees participating in a pension even in those industries where pension participation was very low (below 2\%) prior to the reform. ${ }^{13}$ Given that fewer than $2 \%$ of these employees were enrolled in a pension in 2012, it does not seem conceivable that it is paternalism that, in the face of automatic enrolment for targeted employees, leads to these employers automatically enrolling these non-targeted employees into a pension scheme when they are not obliged to do so.

\section{Conclusion}

With concerns about undersaving for retirement across the developed world, there is intense interest amongst economists and policymakers regarding policies that can boost saving for retirement. This paper has studied the first nationwide introduction of automatic enrolment in which employers are obliged to enrol employees into a workplace pension scheme, which employees can then choose to leave if they wish. We provide the first assessment of the impact of automatic enrolment that allows for changes in employer behaviour in response to the policy in a context where those employers did not choose to introduce automatic enrolment,

\footnotetext{
13 This compares to an increase of 11 percentage points for those employed in industries with high prereform participation.
} 
but instead were obliged to do it. This kind of impact cannot be identified when automatic enrolment is introduced voluntarily by some large employers, such as was studied in Madrian and Shea (2001) and Choi et al. (2004).

We exploit the gradual roll-out by employer size of the obligation in the UK for employers to enrol their targeted employees automatically into a pension between 2012 and 2015 to estimate the effect of automatic enrolment on saving in a workplace pension by private sector employees using a difference-indifferences methodology. We find that the introduction of automatic enrolment substantially increases the probability of participation in a workplace pension scheme, by 36 percentage points. In 2015, after automatic enrolment had been introduced, the workplace pension participation rate for private sector employees who were targeted to be enrolled automatically reached $88 \%$. This is similar to the levels of coverage delivered by automatic enrolment found in Madrian and Shea (2001) and Choi et al. (2004), and is despite the fact that in our setting automatic enrolment is an obligation imposed on employers.

The largest effects on pension participation we find are for those with the lowest participation rates prior to automatic enrolment: those in their 20s, lower-paid employees, those who have joined their employer more recently, and those employed in industries with low pre-reform rates of pension participation. We also find important new evidence that the policy has led to large increases in the participation rate of employees who are not targeted for automatic enrolment, by 18 percentage points on average, likely driven by employers deciding to enrol non-targeted employees automatically as well as targeted employees.

These increases in pension participation have led to large increases in saving in a workplace pension by employees targeted for automatic enrolment, on average increasing the total workplace pension contribution rate (expressed as a percentage of earnings) by $1.05 \%$ of earnings, compared with a pre-reform average of $7.0 \%$. This effect is large in part because a large fraction of employers are making employer contributions above the minimum mandated under the automatic enrolment legislation. While the minimum employer contribution was $1 \%$ of (qualifying) earnings, the proportion of employees receiving more than $2 \%$ of earnings as an employer contribution rose by 8.0 percentage points, and the proportion receiving more than $5 \%$ rose by 3.3 percentage points. This increase in the proportion making contributions that are much higher than the minimum is in contrast to the previous US evidence of individuals reducing their contributions towards the default minimum (Madrian and Shea 2001). We also find no evidence of employers responding to automatic enrolment by reducing the employer contributions to newly hired employees.

Given that we find the automatic enrolment leads to an increase in the average amount of employer contributions that are made to their employee's pensions, a key question is whether employees' wages are reduced in response, or whether automatic enrolment is financed in some other way. The increase in average employer contributions (of $0.6 \%$ of salary) is small relative to the variance of earnings, and therefore our attempts to use the same methodology and data used in this paper to 
look at the effect of automatic enrolment on earnings leaves us with estimates so imprecise that we are unable to rule out wages not falling at all or falling by an amount equivalent to the total increase in employer contributions. Nevertheless, it is a question that it is important for economists and policymakers to answer in future.

Finally, this paper only looks at the effect of saving through a workplace pension. It is possible that increases in saving in a workplace pension are offset by reduced saving elsewhere. However, given that one of the reasons that automatic enrolment is thought to increase pension saving is procrastination (which leads to people not joining in the absence of automatic enrolment and not leaving once they are enrolled), we may not think that many individuals are 'active' enough to reduce their other saving in reaction to automatic enrolment (as is found by Chetty et al. (2014)). Therefore, the substantial increases in workplace pension participation and saving that we have found as a result of the UK's implementation of automatic enrolment are likely to lead to many individuals having higher levels of private resources for retirement than they would have had in the absence of this policy.

Acknowledgements This research is funded by the IFS Retirement Saving Consortium, which comprises Age UK, Association of British Insurers, Chartered Insurance Institute, Department for Work and Pensions, HM Revenue and Customs, HM Treasury, Investment Association, Legal and General Investment Management, Money Advice Service, and Tax Incentivised Savings Association. Support from the ESRC-funded Centre for the Microeconomic Analysis of Public Policy (CPP) at IFS, grant reference ES/ M010147/1, is also gratefully acknowledged. We are grateful to Richard Blundell, Richard Disney, Eric French, Hilary Hoynes, Paul Johnson, Cormac O'Dea, Gemma Tetlow, members of the IFS Retirement Saving Consortium for helpful comments and participants at Netspar International Pension Workshop and the Royal Economic Society Conference. This work is based on data from the Annual Survey of Hours and Earnings, produced by the Office for National Statistics (ONS) and supplied by the Secure Data Service at the UK Data Archive. These data are Crown Copyright. These research data sets may not exactly reproduce National Statistics aggregates. Neither the ONS nor any of the funders of this work bears any responsibility for the analysis or interpretation of the data reported here. All errors are those of the authors.

Open Access This article is distributed under the terms of the Creative Commons Attribution 4.0 International License (http://creativecommons.org/licenses/by/4.0/), which permits unrestricted use, distribution, and reproduction in any medium, provided you give appropriate credit to the original author(s) and the source, provide a link to the Creative Commons license, and indicate if changes were made.

\section{Appendix}

See Tables 7, 8, 9, 10, 11, 12, 13 and 14 . 
Table 7 Staging dates for introduction of automatic enrolment for employers. Source: http://www.nowpension s.com/auto-enrolment-stagi ng-dates

\begin{tabular}{|c|c|}
\hline PAYE scheme size in April 2012 & Staging date \\
\hline 120,000 or more & 1 October 2012 \\
\hline $50,000-119,999$ & 1 November 2012 \\
\hline $30,000-49,999$ & 1 January 2013 \\
\hline $20,000-29,999$ & 1 February 2013 \\
\hline $10,000-19,999$ & 1 March 2013 \\
\hline 6000-9999 & 1 April 2013 \\
\hline $4100-5999$ & 1 May 2013 \\
\hline $4000-4099$ & 1 June 2013 \\
\hline 3000-3999 & 1 July 2013 \\
\hline 2000-2999 & 1 August 2013 \\
\hline $1250-1999$ & 1 September 2013 \\
\hline $800-1249$ & 1 October 2013 \\
\hline $500-799$ & 1 November 2013 \\
\hline $350-499$ & 1 January 2014 \\
\hline $250-349$ & 1 February 2014 \\
\hline $160-249$ & 1 April 2014 \\
\hline $90-159$ & 1 May 2014 \\
\hline $62-89$ & 1 July 2014 \\
\hline 61 & 1 August 2014 \\
\hline 60 & 1 October 2014 \\
\hline 59 & 1 November 2014 \\
\hline 58 & 1 January 2015 \\
\hline $54-57$ & 1 March 2015 \\
\hline $50-53$ & 1 April 2015 \\
\hline $40-49$ & 1 August 2015 \\
\hline $30-39$ & 1 October 2015 \\
\hline Fewer than 30 & 1 June 2015 to 1 April 2017 \\
\hline $\begin{array}{l}\text { New employers (no PAYE income } \\
\text { payable by April 2012) }\end{array}$ & 1 May 2017 to 1 February 2018 \\
\hline
\end{tabular}

The staging dates for employers with fewer than 30 employees in April 2012 are based on the last digits of their PAYE reference number. The staging dates of 'new employers' are based on when they first had PAYE income payable 
Table 8 Characteristics of targeted private sector employees working for employers with 58 or more employees in 2012. Source: Authors' calculations using the Annual Survey of Hours and Earnings
Characteristic

Percentage with each characteristic

Male

Works for non-profit institution

11.5

Works full-time

89.1

Job is second job

Temporary job

Industry (based on SIC2007)

Manufacturing

Retail and wholesale

Transport and storage

Accommodation and food services

Information and communications

Finance and insurance

Mining, electricity and gas

Professional, science and technology

Administrative and support

Education

Health

7.0

Other

9.4

Age (banded)

22-29

30-39

25.8

40-49

50 to state pension age

Years working for employer

$<1$ year

1-2 years

11.4

$2-5$ years

24.2

$\geq 5$ years 
Table 9 Further characteristics of targeted private sector employees working for employers with 58 or more employees in 2012. Source: Authors' calculations using the Annual Survey of Hours and Earnings. Gross weekly pay is rounded to the nearest $£$ per week

\begin{tabular}{lllrr}
\hline Characteristic & Mean & $\begin{array}{l}\text { Standard } \\
\text { deviation }\end{array}$ & Median & N \\
\hline Gross weekly pay (f) & 560 & 346 & 460 & 68,970 \\
Member of workplace pension & 0.49 & 0.50 & 0 & 68,970 \\
Member of DB pension & 0.18 & 0.38 & 0 & 68,970 \\
Employee contribution rate to pension (\% of earnings) & 2.06 & 2.95 & 0 & 68,285 \\
Employer contribution rate to pension (\% of earnings) & 4.94 & 7.09 & 0 & 68,285 \\
Total contribution rate to pension (\% of earnings) & 7.00 & 9.20 & 0 & 68,285 \\
Age (years) & 40.71 & 11.14 & 41 & 68,970 \\
Job tenure (months) & 97.72 & 97.69 & 66 & 68,970 \\
\hline
\end{tabular}

Table 10 Sample sizes: number of targeted private sector employees observed in each 'employer size group' in each year, 2011-2015. Source: Authors' calculations using the Annual Survey of Hours and Earnings

\begin{tabular}{llllllll}
\hline Year & \multicolumn{6}{l}{ Number of employees in employer in April 2012: } \\
\cline { 2 - 8 } & $30,000+$ & $6000-29,999$ & $350-5999$ & $160-349$ & $58-159$ & $50-57$ & $5-49$ \\
\hline 2011 & 8162 & 13,933 & 29,118 & 7913 & 10,267 & 1472 & 19,201 \\
2012 & 8207 & 14,607 & 28,730 & 7479 & 9947 & 1470 & 18,403 \\
2013 & 8439 & 14,517 & 30,267 & 7844 & 10,200 & 1499 & 18,925 \\
2014 & 9790 & 14,456 & 30,682 & 8039 & 10,503 & 1563 & 19,184 \\
2015 & 8314 & 14,237 & 29,309 & 7847 & 10,451 & 1680 & 20,788 \\
\hline
\end{tabular}

Table 11 Effect of automatic enrolment on workplace pension participation among targeted employees: OLS regression results. Source: Authors' calculations using the Annual Survey of Hours and Earnings

\begin{tabular}{lll}
\hline Independent variable & Effect & Standard error \\
\hline Auto-enrolment (AE) in place & $0.361^{* * *}$ & {$[0.016]$} \\
AE partially introduced (2013) & $0.067^{* * *}$ & {$[0.020]$} \\
AE partially introduced (2014) & $0.170^{* * *}$ & {$[0.010]$} \\
AE partially introduced (2015) & $0.204^{* * *}$ & {$[0.015]$} \\
Year is 2012 & $-0.007 * *$ & {$[0.003]$} \\
Year is 2013 & -0.004 & {$[0.007]$} \\
Year is 2014 & 0.002 & {$[0.005]$} \\
Year is 2015 & $0.032^{* * *}$ & {$[0.006]$} \\
Employer size: 6000-29,999 & -0.043 & {$[0.043]$} \\
Employer size: $350-5999$ & -0.037 & {$[0.042]$} \\
Employer size: $160-349$ & $-0.075^{*}$ & {$[0.043]$} \\
\hline
\end{tabular}


Table 11 (continued)

\begin{tabular}{|c|c|c|}
\hline Independent variable & Effect & Standard error \\
\hline Employer size: $58-159$ & $-0.137 * * *$ & {$[0.043]$} \\
\hline Employer size: 50-57 & $-0.200 * * *$ & {$[0.045]$} \\
\hline Employer size: 5-49 & $-0.280 * * *$ & {$[0.044]$} \\
\hline Male & $0.009 * * *$ & {$[0.003]$} \\
\hline Age & -0.008 & {$[0.005]$} \\
\hline Age squared & $0.000 * * *$ & {$[0.000]$} \\
\hline Age cubed & $0.000 * * *$ & {$[0.000]$} \\
\hline Non-profit institution & $0.091 * * *$ & {$[0.008]$} \\
\hline Full-time job & $0.034 * * *$ & {$[0.006]$} \\
\hline Non-main job & $-0.146^{* * *}$ & {$[0.013]$} \\
\hline Temporary job & $-0.079 * * *$ & {$[0.010]$} \\
\hline North West & 0.010 & {$[0.009]$} \\
\hline Yorkshire and the Humber & 0.003 & {$[0.010]$} \\
\hline East Midlands & $0.017 *$ & {$[0.010]$} \\
\hline West Midlands & 0.008 & {$[0.010]$} \\
\hline South West & $0.032 * * *$ & {$[0.009]$} \\
\hline East & $0.034 * * *$ & {$[0.009]$} \\
\hline London & $0.033 * * *$ & {$[0.009]$} \\
\hline South East & $0.048 * * *$ & {$[0.009]$} \\
\hline Wales & $0.024 * *$ & {$[0.012]$} \\
\hline Scotland & $0.040 * * *$ & {$[0.009]$} \\
\hline Industry: retail and wholesale & $-0.134 * * *$ & {$[0.013]$} \\
\hline Industry: transport and storage & $-0.035^{*}$ & [0.019] \\
\hline Industry: accommodation and food services & $-0.206 * * *$ & {$[0.012]$} \\
\hline Industry: information and communications & $-0.030 * *$ & {$[0.014]$} \\
\hline Industry: finance and insurance & $0.070^{* * *}$ & {$[0.016]$} \\
\hline Industry: mining, electricity and gas & $0.103 * * *$ & {$[0.021]$} \\
\hline Industry: professional, science and technology & $-0.029 * * *$ & {$[0.010]$} \\
\hline Industry: administrative and support & $-0.167 * * *$ & {$[0.014]$} \\
\hline Industry: education & $-0.028 * *$ & {$[0.011]$} \\
\hline Industry: health & $-0.113^{* * *}$ & [0.013] \\
\hline Industry: other services & $-0.119 * * *$ & {$[0.011]$} \\
\hline Industry: other-not services & $-0.110^{* * *}$ & {$[0.009]$} \\
\hline Occupational group: professionals & $0.061 * * *$ & {$[0.005]$} \\
\hline Occupational group: associated professionals & $0.012 * *$ & {$[0.005]$} \\
\hline Occupational group: administrative/secretarial & $-0.017 * * *$ & {$[0.005]$} \\
\hline Occupational group: skilled trades & $-0.093 * * *$ & {$[0.006]$} \\
\hline
\end{tabular}


Table 11 (continued)

\begin{tabular}{lcc}
\hline Independent variable & Effect & Standard error \\
\hline Occupational group: caring/leisure & $-0.171^{* * *}$ & {$[0.012]$} \\
Occupational group: sales/customer service & $-0.115^{* * *}$ & {$[0.008]$} \\
Occupational group: plant and machinery & $-0.145^{* * *}$ & {$[0.008]$} \\
Occupational group: elementary occupations & $-0.143^{* * *}$ & {$[0.008]$} \\
Job tenure: $1-2$ years & $0.036^{* * *}$ & {$[0.003]$} \\
Job tenure: $2-5$ years & $0.072^{* * *}$ & {$[0.003]$} \\
Job tenure: 5 years or more & $0.181^{* * *}$ & {$[0.004]$} \\
Constant & $0.399^{* * *}$ & {$[0.063]$} \\
\hline
\end{tabular}

***Denotes that the effect is significantly different from zero at the $1 \%$ level, $* *$ at the $5 \%$ level and * at the $10 \%$ level. Estimated by OLS with standard errors clustered at the employer level. This regression model uses private sector employees targeted for automatic enrolment, excluding those working for employers with 1-4 employees in 2012. Years included: 2011-2015. Number of observations: 457,443. Omitted categorical variables: year $=2011$, employer size $=30,000+$, region $=$ North East, industry $=$ manufacturing, occupation group $=$ managerial, job tenure $=$ less than 1 year. Industry is measured using Standard Industrial Classification 2007 (main letter). Occupational group is measured using Standard Occupational Classification 2010 (one-digit)

Table 12 Placebo test: testing for any evidence of an effect had automatic enrolment been introduced 3 years earlier. Source: Authors' calculations using the Annual Survey of Hours and Earnings

\begin{tabular}{lll}
\hline & \multicolumn{2}{l}{ Specification } \\
\cline { 2 - 3 } & $(1)$ & $(2)$ \\
\hline Effect of placebo 'automatic enrolment' & 0.002 & 0.002 \\
Standard error & {$[0.005]$} & {$[0.005]$} \\
Number of observations & 350,848 & 350,848 \\
Number of clusters & 56,308 & 56,308 \\
Estimated by: & OLS & Probit \\
Control variables $(X)$ included? & Yes & Yes \\
\hline
\end{tabular}

***Denotes that the effect is significantly different from zero at the $1 \%$ level, ** at the 5\% level and * at the $10 \%$ level. Probit models are estimated using maximum likelihood. Standard errors are clustered at the employer level and for specification 2 are estimated by bootstrapping the average marginal effect of the (placebo) policy dummy on pension par 250 times. Control variables $(X)$ are listed in Appendix Table 11. Sample includes all targeted private sector employees from April 2009 to April 2012 
Table 13 Effect of automatic enrolment on pension saving outcomes, split by employer size in 2012 . Source: Authors' calculations using the Annual Survey of Hours and Earnings

\begin{tabular}{|c|c|c|c|c|}
\hline Outcome & $\begin{array}{l}\text { Effect of auto- } \\
\text { enrolment }\end{array}$ & Std error & $\begin{array}{l}\text { Number of } \\
\text { employers }\end{array}$ & Sample size \\
\hline \multicolumn{5}{|c|}{ Panel A: Effect on employers with 30,000 or more employees in 2012} \\
\hline Member of pension scheme & $0.297 * * *$ & [0.077] & 5136 & 155,980 \\
\hline Total contribution above $2 \%$ & $0.115^{* *}$ & [0.047] & 5136 & 155,980 \\
\hline Total contribution above $5 \%$ & $0.061 * *$ & [0.029] & 5136 & 155,980 \\
\hline Total contribution above $10 \%$ & 0.016 & [0.027] & 5136 & 155,980 \\
\hline \multicolumn{5}{|c|}{ Panel B: Effect on employers with 58-159 employees in 2012} \\
\hline Member of pension scheme & $0.414 * * *$ & {$[0.007]$} & 42,355 & 94,793 \\
\hline Total contribution above $2 \%$ & $0.123 * * *$ & {$[0.006]$} & 42,355 & 94,793 \\
\hline Total contribution above $5 \%$ & $0.042 * * *$ & [0.005] & 42,355 & 94,793 \\
\hline Total contribution above $10 \%$ & $0.012 * * *$ & [0.004] & 42,355 & 94,793 \\
\hline
\end{tabular}

***Denotes that the effect is significantly different from zero at the $1 \%$ level, ** at the $5 \%$ level and $*$ at the 10\% level. Effects in Panel A are estimated by estimating Eq. (1) using data from 2011 to 2013 on employers with 350 or more employees in 2012. Effects in Panel B are estimated by estimating Eq. (1) using data from 2013 to 2015 on employers with 5-159 employees in 2012. Standard errors are clustered at the employer level. Control variables $(X)$ are listed in Appendix Table 11

Table 14 Effect of automatic enrolment on pension participation of non-targeted employees, based on pre-reform pension participation in the industry of work. Source: Authors' calculations using the Annual Survey of Hours and Earnings

\begin{tabular}{lllllll}
\hline $\begin{array}{l}\text { Pension membership } \\
\text { in industry (pre- } \\
\text { reform) }\end{array}$ & $\begin{array}{l}\text { Effect of } \\
\text { auto-enrol- } \\
\text { ment }\end{array}$ & Std error & $\begin{array}{l}\text { Number of } \\
\text { employers }\end{array}$ & Sample size & $\begin{array}{l}\text { Participation } \\
\text { in 2012 }(\%)\end{array}$ & $\begin{array}{l}\text { Participa- } \\
\text { tion in 2015 } \\
(\%)\end{array}$ \\
\hline Low & $0.184^{* * *}$ & {$[0.030]$} & 13,734 & 58,236 & 1.9 & 19.0 \\
Medium & $0.131^{* * *}$ & {$[0.011]$} & 15,205 & 76,838 & 10.5 & 27.2 \\
High & $0.106^{* * *}$ & {$[0.011]$} & 11,247 & 34,772 & 28.2 & 42.4 \\
\hline
\end{tabular}

***Denotes that the effect is significantly different from zero at the $1 \%$ level, ** at the $5 \%$ level, * at the $10 \%$ level. Estimated by OLS including control variables listed in Appendix Table 11

\section{References}

Benartzi, S., \& Thaler, R. (2007). Heuristics and biases in retirement savings behavior. Journal of Economic Perspectives, 21(3), 81-104.

Benartzi, S., \& Thaler, R. (2013). Behavioral economics and the retirement savings crisis. Science, $339(6124), 1152-1153$.

Beshears, J., Choi, J., Laibson, D., \& Madrian, B. (2009). The importance of default options for retirement savings outcomes: Evidence from the United States. In J. Brown, J. Liebman, \& D. Wise (Eds.), Social security policy in a changing environment. Chicago: University of Chicago Press.

Brady, P. (2007). Pension nondiscrimination rules and the incentive to cross subsidize employees. Journal of Pension Economics and Finance, 6(2), 127-145.

Butrica, B. A., \& Karamcheva, N. S. (2015). Automatic enrollment, employer match rates, and employee compensation in 401(k) plans. Monthly labor review/U.S. Department of Labor, Bureau of Labor Statistics. https://doi.org/10.21916/mlr.2015.15. 
Chetty, R. (2015). Behavioral economics and public policy: A pragmatic perspective. American Economic Review, 105(5), 1-33.

Chetty, R., Friedman, J., Leth-Petersen, S., Nielsen, T., \& Olsen, T. (2014). Active vs. passive decisions and crowd-out in retirement savings accounts: Evidence from Denmark. Quarterly Journal of Economics, 129(3), 1141-1219.

Choi, J., Laibson, D., Madrian, B., \& Metrick, A. (2002). Defined contribution pensions: Plan rules, participant decisions and the path of least resistance. In J. Poterba (Ed.), Tax Policy and the Economy, Cambridge. MA: MIT Press.

Choi, J., Laibson, D., Madrian, B., \& Metrick, A. (2004). For better or worse: Default effects and 401(k) savings behaviour. In D. Wise (Ed.), Perspectives in the Economics of Aging, Chicago. IL: University of Chicago Press.

Crawford, R., \& O'Dea, C. (2012) The adequacy of wealth among those approaching retirement. Report R72, London: Institute for Fiscal Studies. https://www.ifs.org.uk/publications/6403. Accessed 1 Nov 2018.

Cribb, J., \& Emmerson, C. (2016a). Workplace pensions and remuneration in the public and private sectors in the UK. National Institute Economic Review, 237, R30-R37.

Cribb, J., \& Emmerson, C. (2016b). What happens when employers are obliged to nudge? Automatic enrolment and pension saving in the UK. IFS working paper no. 16/9. https://www.ifs.org.uk/ uploads/publications/wps/wp1619.pdf. Accessed 1 Nov 2018.

Department for Work and Pensions. (2016). Employers' Pension Provision Survey 2015. DWP research report no. 919 .

Duflo, E., \& Saez, E. (2002). Participation and investment decisions in a retirement plan: The influence of colleagues' choices. Journal of Public Economics, 85(1), 121-148.

Executive Office of the President. (2016). National Science and Technology Council. Social and Behavioral Sciences Team 2016 Annual Report

Madrian, B. (2014). Applying insights from behavioral economics to policy design. Annual Review of Economics, 6(1), 663-688.

Madrian, B., \& Shea, D. (2001). The power of suggestion: Inertia in 401(k) participation and savings behavior. Quarterly Journal of Economics, 116(4), 1149-1187.

McKay, S. (2006). Employers' pension provision survey 2005, DWP Research Report 329. http:// webarchive.nationalarchives.gov.uk/20130314010347/http://research.dwp.gov.uk/asd/asd5/rport s2005-2006/rrep329.pdf. Accessed 1 Nov 2018.

Munnell, A., Belbase, A., \& Sanzenbacher, G. (2016). State initiatives to cover uncovered private sector workers. Centre for Retirement Research, Brief IB\#16-4.

O’Donoghue, T., \& Rabin, M. (1999). Doing it now or later. American Economic Review, 89(1), $103-124$.

OECD. (2015). Pensions at a Glance 2015: OECD and G20 indicators, OECD Publishing, Paris. https:// doi.org/10.1787/pension_glance-2015-en.

Office for National Statistics. (2018). Annual survey of hours and earnings, 1997-2015: Secure access (data collection), 12th Ed. UK Data Service. SN: 6689, http://doi.org/10.5255/UKDA-SN-6689-11.

Pensions Commission. (2005). A new pension settlement for the twenty-first century, Second Report of the Pensions Commission, London. http://www.webarchive.org.uk/pan/16806/20070802/www.pensi onscommission.org.uk/publications/2005/annrep/annrep-index.html. Accessed 1 Nov 2018.

Thaler, R. (2016). Behavioral economics: Past, present, and future. American Economic Review, 106(7), 1577-1600.

Tversky, A., \& Shafir, E. (1992). Choice under conflict: The dynamics of deferred decision. Psychological Science, 3(6), 358-361.

Publisher's Note Springer Nature remains neutral with regard to jurisdictional claims in published maps and institutional affiliations. 